\title{
Toxicological study of the butanol fractionated root extract of Asparagus africanus Lam., on some blood parameter and histopathology of liver and kidney in mice
}

\author{
Sintayehu Kebede ${ }^{1 *}$, Mekbeb Afework$^{2}$, Asfaw Debella ${ }^{3}$, Wondwossen Ergete ${ }^{4}$ and Eyasu Makonnen ${ }^{5}$
}

\begin{abstract}
Background: The butanol fractionated root extract of Asparagus africanus Lam., a traditional herb widely used to treat various ailments were analyzed for the presence of potential toxicity after single (acute) and repeated (subchronic) dose oral administration in adult swiss albino mice using gavages.
\end{abstract}

Methods: For the acute study, butanol fractionated extract of the plant was administered in single doses of 1000, 3000 and $5000 \mathrm{mg} / \mathrm{kg}$ body weight. In the sub-chronic dose study, the extract was administered at doses of 300 and $600 \mathrm{mg} / \mathrm{kg}$ body weight/day for 42 days. Selected hematological and biochemical parameters of the blood followed by histopathological analysis were investigated after 42 days of daily administrations. The results were expressed as $\mathrm{M} \pm \mathrm{SE}$, and differences at $\mathrm{P}<0.05$ was considered significant. One way analysis of variance (ANOVA) and least significant difference tests were employed to check the significant differences between the various parameters of the experimental groups.

Results: In the acute study, the extract did not caused dose-dependent general behavioral adverse effects, body weight change and mortality. The single dose toxicity studies therefore showed that the butanol fraction of the extract has high safety profile when given orally. After 42 days of daily dosing, in the sub-chronic study, no clinically significant changes were observed for hematological and biochemical parameters. Except an occasional small number of focal mononuclear lymphocytic cells infiltrations around the central and portal triad of the liver of a few mice, the histopathological parameters do not show significant change.

Conclusion: It is concluded that, the butanol fractionated extract from A. africanus at the given dose does not show significant toxicity. The presence of focal inflammation on the liver of a few mice may be associated to the presence of flavonoid glycoside in the butanol fractionated extract.

Keywords: Asparagus africanus, Butanol fraction, Blood parameters, Histopathology

\section{Background}

Many plants have shown very effective medicinal values for various ailments of human and domestic animals. Studies have witnessed several of the pharmaceuticals currently available to physicians have a long history of

\footnotetext{
*Correspondence: itukuk@yahoo.com

1 Department of Anatomy, Faculty of Medicine, Addis Ababa University, P.O. Box 18309, Addis Ababa, Ethiopia

Full list of author information is available at the end of the article
}

use as herbal remedies. Digoxin and digitoxin, drug for heart failure and atrial dysrhythmias, from digitalis leaves [27]; quinine, antimalarial drug, from cinchona bark [19] and anti-cancer compound bruceatin, from the ethiopian plant, Brucea antidysentrica [14], are examples of the contributions of traditional pharmacopoeia.

Despite its being natural, reputation and continued use over many centuries, recent studies on laboratory animals have shown many plants used as medicinal activity have potential toxicity on blood parameters and 
histopathology of internal organs $[5,7,18]$. In addition, the advancement of technology has enabled to detect minute amounts of carcinogenic and toxic chemicals and recognize potentially hazardous effects of some of the herbs used in traditional medicines [25].

It therefore appears that, although traditional medicine is widely used to treat various diseases and often more available and affordable than modern medicine, it is not without limitations. Asparagus africanus Lam., commonly known with its vernacular name "Seriti" (Afaan Oromo) is one of the most effective medicinal plants widely used to treat malaria [10], impotency [29], diarrhea [1], lishmaniansis, bilharziasis, syphilis and gonorrhoea [26] and fertility [15]. The plant belongs to family Asparagaceae which includes 300 species in the genus Asparagus, widely distributed throughout Africa. It is a perennial shrub or climber with stems up to $6 \mathrm{~m}$ high growing between 700 and $3800 \mathrm{~m}$ above sea level [11, 17]. Different studies have shown antimalarial activity of the plant with different potential of parasitimal suppression. The crude extracts of $A$. africanus for instant have shown a parasitimial suppression of $46.1 \%$ (root parts) and $40.7 \%$ (aerial parts) on Swiss albino mice [12]. The methanol extracts of the plant found to have parasitaemia suppression against Plasomodium berghei at a dose of $200 \mathrm{mg} / \mathrm{kg}$ [12]. Butanol fractionated extract of $A$. africanus showed the highest inhibition $(85.94 \%)$ of P. berghei parasitaemia in the swiss albino mice [10]. In spite of such widespread use of the plant, its safety based on their effective dose is not yet known.

With the problems of increasing drug resistance and difficulties in getting affordable effective antimalarial drugs, traditional medicines, mainly of plant sources could be an important and sustainable ways of treatment if supported by clinical evidences of safety and efficacy. Medicinal plants not only complement modern medicine but also are the basis for the development of modern pharmaceuticals. Despite highest $(85.94 \%)$ inhibition of $P$. bergei parasitaemia, no clinical evidence of safety (toxicity) yet found on butanol fractionated extract of $A$. africanus. This study is therefore aimed to investigate the toxicity of butanol fractionated extract of $A$. africanus Lam., on some blood parameters and histopathology of liver and kidney in mice.

\section{Methods}

\section{Plant material collection and processing}

The fresh root of $A$. africanus were collected from the border of Shashamane and Awassa towns about $270 \mathrm{~km}$ south of Addis Ababa. The plant was identified by a taxonomist in the Traditional and Modern Medicine Drug Research Directorate (formerly called Ethiopian Public Health Institute) at the Ethiopian Public Health Institute (formerly called Ethiopian Health and Nutrition Research Institute). A sample of the plant was deposited at the Herbarium of Traditional and Modern Medicine Drug Research Directorate with Voucher Specimen number Herb No. AA-2163. The collected plant roots were cut into pieces, cleaned from extraneous materials and then dried at ambient temperature $\left(23-26{ }^{\circ} \mathrm{C}\right)$ and grounded to powder using a sample mill.

\section{Hydro-alcoholic extraction of the plant material}

In this study both the hydro-alcoholic extract and solvent fractionation of the plant material were done as the method employed on efficacy study by Debebe [10]. Briefly, hydro-alcoholic extract yields were obtained by soaking $400 \mathrm{~g}$ of plant powder in $3 \mathrm{~L}$ of $70 \%$ ethanol to fully immerse and wet the plant powder. These were placed on orbital shaker rotating $120 \mathrm{rpm}$ for $48 \mathrm{~h}$ for regular infusion. On the 3rd day, the mixture was left to settle and the clear decanted supernatant was filtered using Whatman filter paper No. 3, $18.5 \mathrm{~cm}$, England into a clean container. The extract was then reduced to dryness under low pressure using a rotary vacuum evaporator (BUCHI type R-205, with Aspirator pump, Switzerland) at a temperature of $40{ }^{\circ} \mathrm{C}$ rotating $40 \mathrm{rpm}$. Finally the filtrate in a container was put in a water bath (BUCHI Heating Bath B-490) to remove all the alcohol left in the extract. The crude extract was then stored in labeled sterile glass vials at $-20^{\circ} \mathrm{C}$ until used.

\section{Solvent-solvent fractionation of plant material}

The butanol fractions were obtained after the hydroalcoholic extract were exhaustively defatted respectively with $\mathrm{n}$-hexane (6 repeat) and chloroform (8 repeat) respectively. The aqueous residue after de-fat was further partitioned with $50 \mathrm{ml}$ of $\mathrm{n}$-butanol for eight exhaustive separate and successive mixing and filtrations steps. The n-butanol fractionates were then combined, concentrated and labeled as butanol fraction (BF). The weight in the dry extract was expressed as total mass of the powder.

\section{Experimental animal preparation}

The study was conducted on Swiss albino mice (weighing 20-25 g) obtained from colonies in the animal unit of the Ethiopian Public Health Institute. The animals were acclimatized to laboratory conditions in the Traditional and Modern Medicine Drug Research Directorate for 1 week prior to the experimental procedure to minimize any nonspecific stress. After a week, body weight of each mouse was measured in gram and recorded as the initial body weight. The mice were housed in standard aluminum cages maintained at normal laboratory conditions of temperature $\left(21 \pm 2{ }^{\circ} \mathrm{C}\right)$, relative humidity of $65 \pm 0.5 \%$ and $12 \mathrm{~h}$ light-dark cycle with free access 
to standard commercial diets and clean tap water adlabium until the end of the experiment based on WHO Annex II Research guidelines for evaluating the safety and efficacy of herbal medicines [30].

\section{Ethical clearance}

Ethical approval for the animal used for this study was obtained from Addis Ababa University Medical Faculty Institutional Review Board Protocol number: 158/09/Anat.

\section{Single dose toxicity study}

The single dose study was carried out in 24 adult female mice randomly distributed into four groups (group I, II, III and IV), each with six mice. The plant extract was orally administered to the mice in groups I, II and III respectively, in a single dose of 1000, 3000 and $5000 \mathrm{mg} /$ $\mathrm{kg}$ body weight, while distilled water was administered to control group (group IV) using a stomach tube gavages based on WHO Annex II; research guidelines for evaluating the safety and efficacy of herbal medicines [30]. Changes like muscular weakness, behavior change, salivation, diarrhea, body weight and food intake in comparison to the controls, were recorded separately for each animal for 14 days.

\section{Repeated dose toxicity study \\ Selection of dose and duration of dosing}

Effective dose for parasitimal suppression $300 \mathrm{mg} / \mathrm{kg}$ body weight [10] and its double (i.e., $600 \mathrm{mg} / \mathrm{kg}$ body weight) were selected for repeated dose toxicological investigation of the plant extract as the appropriate doses for this particular study for 42 days [30].

\section{Administration of the extract}

For repeated dose toxicity study, 36 mice were randomly distributed into three groups, each with 12 mice and were assigned as group I, II and III. group I and II were respectively treated with 300 and $600 \mathrm{mg} / \mathrm{kg}$ body weight, while mice in group III were treated with vehicle (distilled water) [30]. Administrations of the extract as well as the vehicle into the mice were done orally by using stomach tube gavages [30].

\section{Hematological and biochemical parameters and histopathology of liver and kidney}

After $24 \mathrm{~h}$ of the administration of the extract for the last time, i.e., at the end of the 6th week, the animals were anaesthetized under diethyl ether and blood sample for bioassays was immediately collected from each mouse by a cardiac puncture using sterile needle and syringe for evaluation of any change in hematological and biochemical parameters [30]. Following collection of blood sample, tissue section from liver and kidney of all mice in each groups were immediately removed and processed for section preparation for light microscopy (fixed, dehydrated, cleared, impregnated, sectioned and placed in microscopic slides) and stained with Hrris hematoxylin and counterstained in $1 \%$ alcoholic eosin for microscopic slides. At the end of every week, change in body weight was analyzed by recording the body weight of each animal.

\section{Statistical analysis}

All data were packed and analyzed by SPSS statistical Microsoftware. Mean values $(\mathrm{M})$ and standard errors (SE) of the parameters were calculated and the results were expressed as $\mathrm{M} \pm \mathrm{SE}$. One way analysis of variance (ANOVA) and least significant difference tests were employed to check the significant differences between the various parameters of the experimental groups. In addition, Dunnett t-tests which treat one group as a control, and compare all other groups against it was employed to compare the values within a parameter and to evaluate the relationship between the variables. Differences at $\mathrm{P}<0.05$ was considered significant.

\section{Results}

Effect of single dose treatment of the butanol fractionated extract of Asparagus africanus

Following a single treatment with fractionated extract of A. africanus at doses of 1000,3000 and $5000 \mathrm{mg} / \mathrm{kg}$ body weight, no signs and symptoms of toxicity on behavior nor death were observed throughout the 14 days of the study period. Comparison of body growth patterns and body weight gains between the test groups and the control showed no significant differences as shown in Table 1.

\section{Effect of repeated dose treatment of the fraction of Asparagus africanus}

Effects of the fraction on hematological parameters of blood No statistical significant (at $\mathrm{P}>0.05$ ) change was observed in the hematological parameters of the mice treated with the repeated doses of 300 and $600 \mathrm{mg} / \mathrm{kg}$ body weight/day of the fractionated extracts of $A$. africanus as compared to the controls as shown in Table 2. However, a non-significant increase in WBC in both groups, decrease in platelet count in mice treated with $600 \mathrm{mg} / \mathrm{kg}$ and increase in mice treated with $300 \mathrm{mg} / \mathrm{kg}$ were seen as compared to the control.

\section{Effects of the fraction on biochemical parameters of the blood}

Values of the functional tests for liver (AST, ALP and ALT) and kidney (urea and creatinine) in the extract treated mice as compared to those of the controls are 
Table 1 Comparison of body weight change among butanol fractionated extract of $A$. africanus treated groups, at doses of 1000,3000 and $5000 \mathrm{mg} / \mathrm{kg}$ body weight and control mice during the 14 days of observation

\begin{tabular}{lllll}
\hline Group & Dose $(\mathbf{m g} / \mathbf{k g})$ & Initial body weight & Body weight at day $\mathbf{7}$ & Final body weight at day 14 \\
\hline III & 1000 & $20.84 \pm 0.80$ & $27.62 \pm 0.40$ & $30.46 \pm 0.45$ \\
II & 3000 & $20.83 \pm 0.35$ & $27.57 \pm 0.70$ & $30.13 \pm 0.48$ \\
I & 5000 & $21.43 \pm 0.54$ & $27.94 \pm 0.71$ & $30.90 \pm 0.69$ \\
IV & Control & $20.66 \pm 0.44$ & $26.90 \pm 0.68$ & $30.07 \pm 0.45$ \\
\hline
\end{tabular}

Data are expressed as mean $\pm S E M, n=6 /$ group

Table 2 Comparison of hematological parameters among fractionated extract of $A$. africanus treated groups at doses of 300 and $600 \mathrm{mg} / \mathrm{kg}$ body weight/day, and the control mice

\begin{tabular}{|c|c|c|c|c|c|c|c|}
\hline \multirow{2}{*}{$\begin{array}{l}\text { Hematological } \\
\text { parameter }\end{array}$} & \multirow[t]{2}{*}{ Control } & \multicolumn{3}{|c|}{300 mg/kg bwt } & \multicolumn{3}{|l|}{600 mg/kg bwt } \\
\hline & & Values & $\begin{array}{l}\text { \% of mean } \\
\text { difference }\end{array}$ & $P$ value & Values & $\begin{array}{l}\text { \% of mean } \\
\text { difference }\end{array}$ & $P$ value \\
\hline $\mathrm{RBC}\left(\times 10^{6} / \mu \mathrm{L}\right)$ & $10.93 \pm 0.38$ & $11.48 \pm 0.46$ & 4.79 & 0.596 & $11.33 \pm 0.64$ & 3.55 & 0.468 \\
\hline Hemoglobin (g/dL) & $15.63 \pm 0.75$ & $16.47 \pm 0.58$ & 5.10 & 0.383 & $16.57 \pm 0.75$ & 5.67 & 0.433 \\
\hline Hematocrit (\%) & $56.97 \pm 1.72$ & $60.20 \pm 2.29$ & 5.37 & 0.756 & $56.05 \pm 1.91$ & -1.61 & 0.294 \\
\hline $\mathrm{MCV}(\mathrm{fL})$ & $52.17 \pm 0.63$ & $52.47 \pm 1.27$ & 0.57 & 0.662 & $52.83 \pm 1.07$ & 1.25 & 0.843 \\
\hline $\mathrm{MCH}(\mathrm{pg})$ & $14.30 \pm 0.21$ & $14.33 \pm 0.29$ & 0.21 & 0.309 & $14.70 \pm 0.27$ & 2.72 & 0.929 \\
\hline $\mathrm{MCHC}(\mathrm{g} / \mathrm{dL})$ & $27.40 \pm 0.59$ & $27.37 \pm 0.15$ & -0.11 & 0.593 & $27.80 \pm 0.63$ & 1.44 & 0.964 \\
\hline $\operatorname{PLAT}\left(10^{3} / \mu \mathrm{L}\right)$ & $581.00 \pm 38.2$ & $702.67 \pm 99.3$ & 35.56 & 0.564 & $455.33 \pm 288.7$ & -21.67 & 0.169 \\
\hline $\operatorname{WBC}\left(10^{3} / \mu \mathrm{L}\right)$ & $4.76 \pm 1.42$ & $6.76 \pm 2.36$ & 29.59 & 0.352 & $7.97 \pm 2.76$ & 40.28 & 0.553 \\
\hline
\end{tabular}

Data are expressed as mean \pm SEM, $\mathrm{n}=12$

Bwt body weight

shown in Table 3. All these values of the functional test showed no significant change.

\section{Effect of the fraction on behavior and body weight}

Daily cage-side observations did not reveal any physical changes in the skin, fur, eyes, and respiratory system and general behavioral patterns. No autonomic effect such as salivation, diarrhea and urination were observed throughout the 42 days of administration period as compared to the controls. All of the treated as well as control mice survived until the scheduled necropsy. Macroscopic autopsy examination also did not reveal any pathological findings in the liver and kidneys. Comparable increase in body weight gains were observed for all the extract as well as the control mice as shown in Table 4 .

\section{Effect of the fraction on the histology of the liver}

Microscopic examination of tissue sections of liver under light microscope from mice treated with the butanol fractionated extract of A. africanus at 300 and $600 \mathrm{mg} /$ $\mathrm{kg}$ body weight/day doses showed no treatment related pathological findings and were comparable to those of the controls. However, there were occasional focal mononuclear lymphocytic cellular infiltration around the portal and central vein of few slides as shown in Fig. 1a-d.

\section{Effect of the fraction on histology of the kidney}

Microscopic examinations of tissue sections of the kidney from the butanol fractionated extract treated mice at 600 and $300 \mathrm{mg} / \mathrm{kg}$ body weight/day doses showed normal histology with no evident of treatment related changes as compared to those of controls Fig. 2.

\section{Discussion}

In this study, to determine the LD50, the butanol fractionated extract with a minimum dose of 1000 and a maximum dose of $3000 \mathrm{mg} / \mathrm{kg}$ body weight were first tried in a single administration. As recommended by WHO guide line for dose selection, the dose was then raised to $5000 \mathrm{mg} / \mathrm{kg}$ body weight. In all the three doses, the mice treated with extract did not show change in food consumption, behavioral patterns, body temperature, and respiratory rate. No autonomic effects such as salivation, diarrhea and urination were seen. There were comparable body weight gains among the extract treated mice as compared to those of the controls. All the treated mice survived until the scheduled necropsy. This finding therefore, suggested that the LD50 of the fractionated extract appears to be greater than $5000 \mathrm{mg} / \mathrm{kg}$ body weight. Hence, the single dose administration of the extract has high safety profile when given orally. 
Table 3 Comparison of biochemical parameters among fractionated extract of $A$. africanus treated groups, at doses of 300 and $600 \mathrm{mg} / \mathrm{kg}$ body weight/day, and the control mice

\begin{tabular}{|c|c|c|c|c|c|c|c|}
\hline \multirow{2}{*}{$\begin{array}{l}\text { Biochemical } \\
\text { parameters }\end{array}$} & \multirow[t]{2}{*}{ Control } & \multicolumn{3}{|l|}{300 mg/kg bwt } & \multicolumn{3}{|l|}{$600 \mathrm{mg} / \mathrm{kg} \mathrm{bwt}$} \\
\hline & & Value & $\begin{array}{l}\% \text { of mean } \\
\text { difference }\end{array}$ & $P$ value & Value & $\begin{array}{l}\% \text { of mean } \\
\text { difference }\end{array}$ & $P$ value \\
\hline $\begin{array}{l}\text { AST } \\
(I U / L)\end{array}$ & $208.17 \pm 44.84$ & $208.17 \pm 51.63$ & 0 & 1.00 & $261.20 \pm 32.38$ & 17.06 & 0.49 \\
\hline $\begin{array}{l}\text { ALP } \\
(I U / L)\end{array}$ & $74.00 \pm 29.46$ & $75.00 \pm 10.25$ & 1.33 & 0.34 & $76.32 \pm 31.45$ & 3.03 & 0.25 \\
\hline $\begin{array}{l}\text { ALT } \\
(I U / L)\end{array}$ & $107.50 \pm 34.88$ & $84.67 \pm 9.64$ & -21.24 & 0.47 & $82.80 \pm 13.41$ & -25 & 0.40 \\
\hline $\begin{array}{l}\text { Urea } \\
(\mathrm{mg} / \mathrm{dL})\end{array}$ & $49.00 \pm 2.91$ & $52.33 \pm 6.92$ & 6.36 & 0.60 & $46.40 \pm 1.33$ & -6.47 & 0.62 \\
\hline $\begin{array}{l}\text { Creatnine (mg/ } \\
\quad \mathrm{dL} \text { ) }\end{array}$ & $0.88 \pm 0.11$ & $0.83 \pm 0.11$ & -5.68 & 0.75 & $1.24 \pm 0.16$ & 26.67 & 0.08 \\
\hline
\end{tabular}

Data are expressed as Mean $\pm \mathrm{SEM}, \mathrm{n}=12$

Table 4 Comparison of body weight change among fractionated extract of $A$. africanus treated groups, at doses of 300 and $600 \mathrm{mg} / \mathrm{kg}$ body weight/day, and the control mice

\begin{tabular}{|c|c|c|c|c|c|c|c|}
\hline Group & $\begin{array}{l}\text { Week } 0 \\
\text { bwt (g) }\end{array}$ & $\begin{array}{l}\text { Week } 1 \\
\text { bwt (g) }\end{array}$ & $\begin{array}{l}\text { Week } 2 \\
\text { bwt (g) }\end{array}$ & $\begin{array}{l}\text { Week } 3 \\
\text { bwt (g) }\end{array}$ & $\begin{array}{l}\text { Week } 4 \\
\text { bwt (g) }\end{array}$ & $\begin{array}{l}\text { Week } 5 \\
\text { bwt (g) }\end{array}$ & $\begin{array}{l}\text { Week } 6 \\
\text { bwt (g) }\end{array}$ \\
\hline G1 & $135.23 \pm 2.31$ & $144.18 \pm 8.76$ & $148.79 \pm 11.79$ & $156.28 \pm 14.88$ & $158.05 \pm 32.20$ & $154.93 \pm 27.53$ & $179.73 \pm 16.17$ \\
\hline G2 & $135.82 \pm 1.37$ & $158.97 \pm 16.62$ & $161.23 \pm 16.12$ & $162.81 \pm 13.54$ & $176.86 \pm 15.29$ & $173.11 \pm 8.67$ & $184.93 \pm 13.33$ \\
\hline G3 & $135.63 \pm 3.52$ & $162.29 \pm 16.81$ & $166.42 \pm 18.99$ & $171.05 \pm 20.35$ & $180.33 \pm 27.41$ & $180.01 \pm 23.02$ & $193.46 \pm 21.56$ \\
\hline
\end{tabular}

Values are expressed as mean $\pm \mathrm{SEM} ; \mathrm{n}=12$

Analysis of red blood cell indices (Table 2) showed no significant reduction following repeated administration of the butanol fractionated extract of $A$. africanus. This result indicates neither lysis nor inhibition in blood cells synthesis by any of the active constituents that may exist in fractionated extract of $A$. africanus. The unlikelihood of the extract to induce anemia even after long use on red blood cell indices may be due to the inability of the extract to distract the matured red blood cell and inhibit erythropoiesis. This is in agreement with other related studies like the long term treatment with Teucrium polium total extract and its failure to induce any toxic effect on the matured red blood cells and hence was suggested to induce no anemia [16]. On the other hand, chronic treatments with plants extract like S. lycopersicum, M. perennis, M. annua, E. balsamifera, E. hirta, E. heterophylla, E. lateriflora, E. hyssopifolia and Cassia italica are known to cause destruction of hematological parameters leading to anemia in animals [3, 4, 20].

Leukocytes are known to increase sharply as the first line defense of the body or in response to toxic environment when infection occurs. The absence of significant increase in the WBC after 42 days of chronic treatment with the extract suggests for lack of damaging toxic effect of the plant extract on the mice. The non-significant increases of the treated mice at $\mathrm{P}<0.05$ observed in the WBC count by $29.59 \%$ and $40.28 \%$, respectively for 300 and $600 \mathrm{mg} / \mathrm{kg} /$ body weight doses as compared to the control may probably be due to the normal responses of the mice to foreign bodies or stress associated with the sub-chronic toxicity of the extract. It is known that chronic treatment with some plant extract cause a non significant increase in WBC parameter as a normal response to the extract $[2,21]$.

Significant elevation of platelets (thrombocytosis) could predispose to hypercoagulable state, which results to spontaneous intravascular clotting and thromboembolism that may lead to stroke and heart attack [6, 7]. On the other hand, significant decrease in platelets (thrombocytopaenia) could increase the tendency to bleed and have anticoagulant property [9]. In this study, the observation that platelets count was not affected significantly at any of the dose employed suggests that the fraction does not interfere with coagulation.

Generally, following exposure to a toxic substance, a significant reduction in body weight by more than $10 \%$ from the initial body weight is a simple and sensitive index of toxicity [28]. In this study administration of the extract of $A$. africanus for 42 days at both of the investigated doses, apart from slight variation, did not produce 

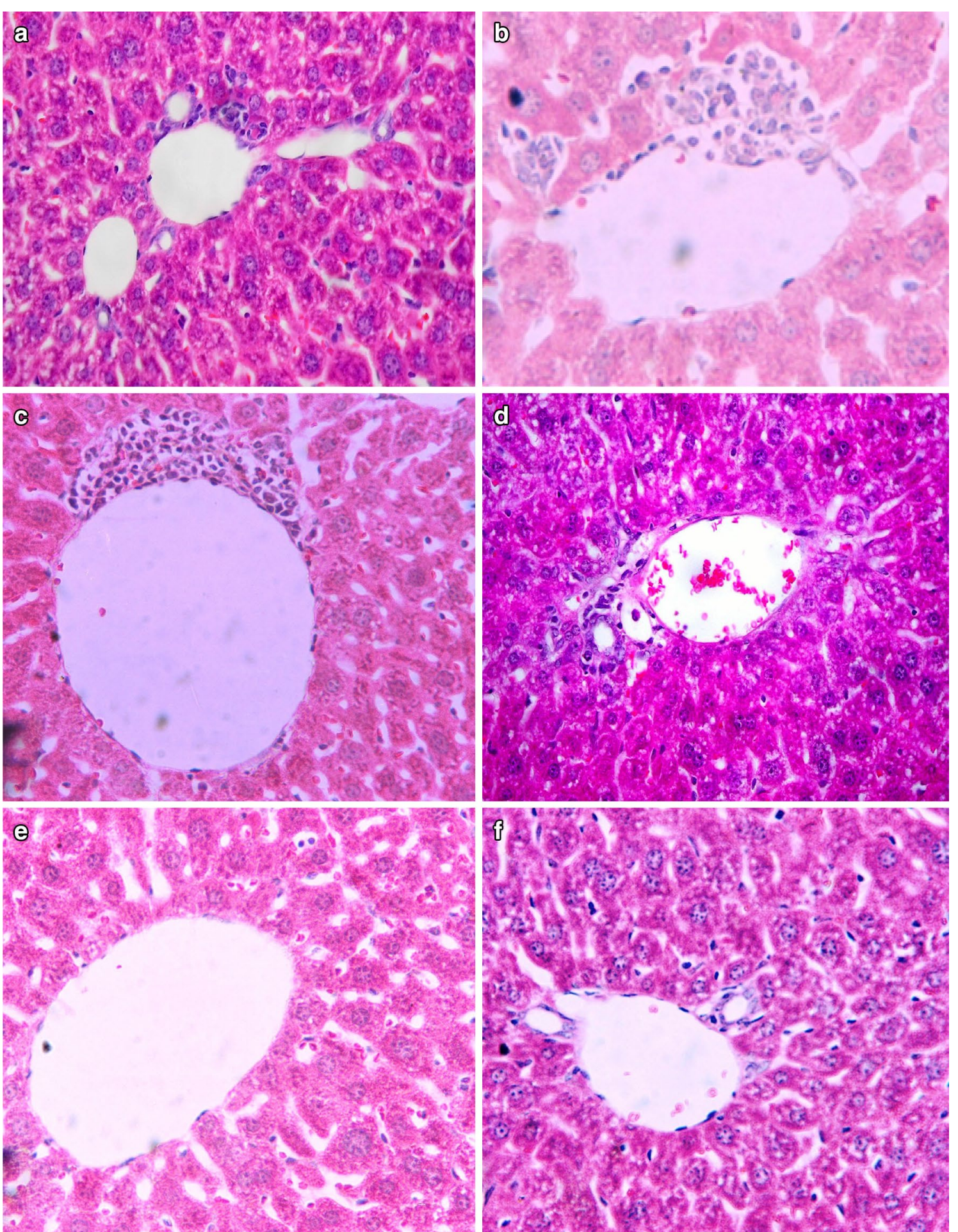

Fig. 1 Photomicrograph of section of mice Liver after 42 days of treatment with butanol fractionated extract of A. africanus at $600 \mathrm{mg} / \mathrm{kg}$ body weight/day (a, c) and $300 \mathrm{mg} / \mathrm{kg}$ body weight/day (b, d) as compared to the control (e, f). Peri-portal vein focal mononuclear lymphocytic cell infiltration around both portal and central veins of the treated mice, and those infiltrations are more around the central veins (sections were stained with $\mathrm{H} \& \mathrm{E}, \times 2000)$ 

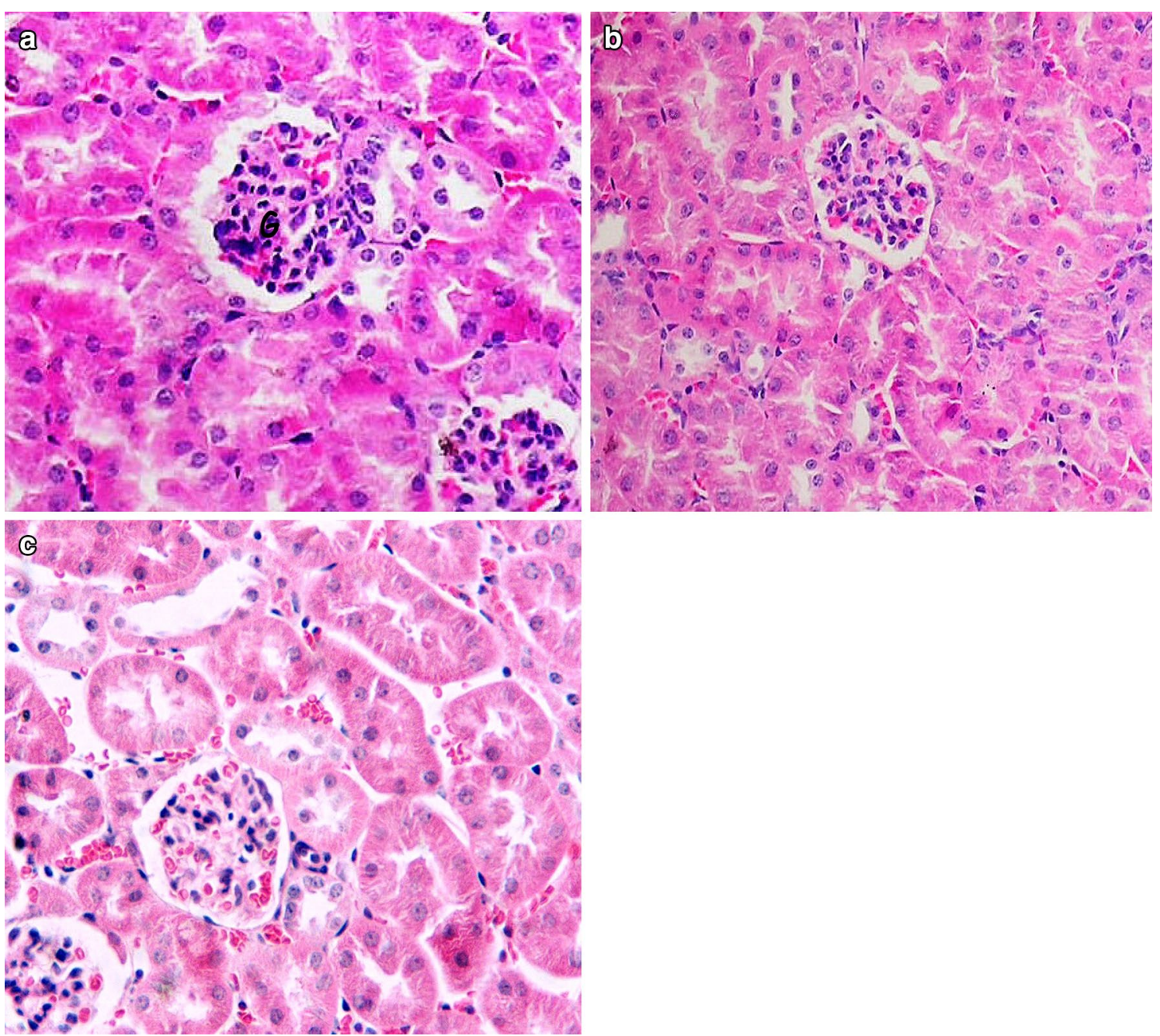

Fig. 2 Photomicrographs of section of the mice kidney of $600 \mathrm{mg} / \mathrm{kg}$ body weight/day dose extract treated mice (a) and $300 \mathrm{mg} / \mathrm{kg}$ body weight/ day $(\mathbf{b})$, as compared to the vehicle treated control mice $(\mathbf{c})$. Sections were stained with $H \& E, \times 2000$ for $\mathbf{a}-\mathbf{c}$

significant change in the body weight as compared to the controls. The slight non-significant differences observed may have resulted from physiological variations in the mice such as food intake and metabolism as suggested in other related study [22]. The lack of adverse effect of the plant on body weight is thus a pointer to the safety of prolonged oral administration of the butanol fractionated extract of $A$. africanus.

After treatment of the butanol fractionated extract at doses of $600 \mathrm{mg} / \mathrm{kg}$ body weight there were trends of increment in AST by $17.06 \%$ and decrement in ALT by $25 \%$ as compared to the control. However, as these were not statistically significant such changes appear not to be extract related. In a comparable study after administration of Glinus lotoides and Hagenia abyssinica the level of ALT decreased and the level of AST increased non-significantly and the author concluded that the extract is not hepatotoxic [23]. Moreover, after sub chronic treatment with butanol fractionated extract of $A$. Africanus at both doses the level of ALP did not change significantly as compared to the control suggesting the extract is not toxic to the liver or damaging to the integrity of the bile duct.

Investigation for the toxic potential of a chemical is incomplete without gross and histopathological evaluation [8]. Following exposure to a toxic substance, a significant reduction in body weight by more than $10 \%$ from the initial body weight is a simple and sensitive index of toxicity [28]. The non significant differences between the weight of mice in the experimental and control group observed in this study may have resulted from physiological variations in the mice such as food 
intake and metabolism as suggested in other related study [22].

Kidneys are particularly vulnerable to toxic agents given their high rate of perfusion by blood and their ability to concentrate a range of substances in the tubular lumen. Following administration of the butanol fractionated extract, a non-significant increase by 5.68 and decrease by $26.67 \%$ of kidney biochemical marker creatinine was seen in mice treated respectively with 300 and $600 \mathrm{mg} / \mathrm{kg}$ body weight/day. Furthermore, the urea level increased non significantly by $6.37 \%$ for mice treated with $300 \mathrm{mg} / \mathrm{kg}$ and decreased non significant by $6.47 \%$ for mice treated with $600 \mathrm{mg} / \mathrm{kg}$ as compared to the control group. The current finding may suggest that the activity of protein metabolism was maintained within the normal range due to relatively non-toxic effect of the extract. Similar suggestion was made after non significant changes in creatinine and urea levels were seen following repeated administration of Sphenocentrum jollyanum extract [24]. Hence the present result probably suggests for absence of any functional damage to the kidney showing the extract did not interfere with the renal capacity to excrete the metabolites.

In the histo-pathological analysis of liver, apart from an occasional small number of focal mononuclear lymphocytic cells infiltration around the central and portal triad no gross or microscopic lesions were found following the 42 days of administration of the extract at 300 and $600 \mathrm{mg} / \mathrm{kg}$ body weight/day doses as compared to the controls. Hence, in this study the extract from A. Africanus appears to be not nephrotoxic at 300 and $600 \mathrm{mg} /$ $\mathrm{kg}$ body weight/day doses studied as they did not show any gross or microscopic lesions. The focal mononuclear lymphocytic cell infiltration observed may be because of the flavonoid glycoside present in the $A$. africanus. However, this should be ascertained by phytochemical screening of $A$. africanus. The presence of glycosides on the other hand has been suggested to cause focal inflammation around the portal triad on the liver with no effect on the kidney [13].

The hematological and biochemical parameters of mice treated with the extract in repeated dose toxicity study showed no significant change as compared to the control mice. Lack of such statistically significant effect may be due to the absences of toxic secondary metabolites in the butanol fractionated extract of $A$. africanus. The non-significant change in biochemical parameters on the other hand tells no tissue damage due to the administration of the extract at 300 and $600 \mathrm{mg} / \mathrm{kg} / \mathrm{body} /$ weight doses in mice. Indeed, such observation in the biochemical parameter is in agreement with the histopathological findings in which no dose related tissue damage appeared, except for the presence of focal mononuclear lymphocytic cell infiltrations around the central vein and portal triad of few mice.

\section{Conclusion}

The present study revealed that the butanol fractionated extract from the root of $A$. Africanus is not hepatonephro- and hemato-toxic at 300 and $600 \mathrm{mg} / \mathrm{kg}$ body weight/day as shown from body weight, biochemical, hematological and histopathological findings. As found from the present study $A$. Africanus is non-toxic at the studied dose in mice and this may call for further investigations including phytochemical screening as well as trial in other animals towards the development of drug from A. Africanus for its claimed traditional therapeutic values.

\section{Abbreviations}

AAU: Addis Ababa University; ALP: alkaline phosphatase; ALT: alanin aminotransferase; AST: asparate aminotransferase; CNS: central nervous system; D.P.X: dibutyl phthalate in xylene; dL: deciliter; EDTA: ethylene diamine tetraacetic acid; $\mathrm{fL}$ : femtoliter; $\mathrm{LD}_{50}$ : lethal dose that kills half of the animals; MCH: mean corpuscular hemoglobin; MF: medical faculty; MCV: mean corpuscular volume; MCHC: mean corpuscular hemoglobin concentration; Pg: pictogram; RBC: red blood cell; SEM: standard error of mean; SPSS: statistical package for social science; WBC: white blood cell; WHO: World Health Organization; $\mu \mathrm{L}$ : microliter.

\section{Authors' contributions}

MA advisor from proposal development guided the histopathological part of the study to the research work to the conclusion as well as preparation of the manuscript. AD provided the research topic and materials support pertinent for this research work, EM contributes from dose selection and dosing up to proofreading of this research work and WE interpretation of the pathological findings. All authors read and approved the final manuscript.

\section{Author details}

${ }_{1}^{1}$ Department of Anatomy, Faculty of Medicine, Addis Ababa University, P.O. Box 18309, Addis Ababa, Ethiopia. ${ }^{2}$ Department of Anatomy,Medical Faculty, Addis Ababa University, Addis Ababa, Ethiopia. ${ }^{3}$ Ethiopian Public Health Institute, Traditional and Modern Medicine Drug Research Directorate, Addis Ababa, Ethiopia. ${ }^{4}$ Department of Pathology, Medical Faculty, Addis Ababa University, Addis Ababa, Ethiopia. ${ }^{5}$ Department of Pharmacology, Medical Faculty, Addis Ababa University, Addis Ababa, Ethiopia.

\section{Acknowledgements}

The authors would like to acknowledge Ethiopia Health and Nutritional Research Institute Department of Drug Research for the research project. The authors also acknowledge Addis Ababa University and Jimma University for the sponsorship of the research project.

\section{Competing interests}

The authors declare that they have no competing interests.

Received: 11 November 2014 Accepted: 14 January 2016

Published online: 27 January 2016

\section{References}

1. Abebe D, Debella A, Urga K. Medicinal plants and other useful plants of Ethiopia. Nairobi: Compriex Publishers International; 2003. p. 63.

2. Adebayo AH, Abolaji AO, Opata TK, Adegbenro IK. Effects of ethanolic leaf extract of Chrysophyllum albidum G. on biochemical and haematological parameters of albino wistar rats. Afr J Biotechnol. 2010;9(14):2145-50. 
3. Adedapo AA, Abatan MO, Olorunsogo OO. Toxic effects of some plants in the genus Euphorbia on haematological and biochemical parameters of rats. Vet Arhiv. 2004;74:53-62.

4. Adedapo AA, Omoloye OA, Ohore OG. Studies on the toxicity of an aqueous extract of the leaves of Abrus precatorius in rats. Onderstepoort J Vet Res. 2007;74:31-6.

5. Adepoju GKA, Odubena OO. Effect of Mucuna pruriens on some haematological and biochemical parameters. J Med Plants Res. 2009;3(2):073-6.

6. Adeyemi OO, Akindele AJ, Nwumeh KI. Acute and subchronic toxicological assessment of Byrsocarpus coccineus Schum. and Thonn. (Connaraceae) aqueous leaf extract. Int J Appl Res Nat Prod. 2010;3(2):1-11.

7. Agbaje EO, Adeneye AA, Daramola AO. Biochemical and toxicological studies of aqueous extract of Syzigium aromaticum Merr. and perry (myrtaceae) in rodents. Africa J Tradit Complement Altern Med. 2009;6(3):241-54.

8. Alavian SM, Alavian SH, Ashayeri N, Babaei M, Daneshbodi M, Hajibeigi B. Prediction of liver histological lesions with biochemical markers in chronic hepatitis B patients in Iran. Gastroenterol Hepatolo Bed Bench. 2010;3(2):71-6.

9. Body SC. Platelet activation and interactions with microvascular. J Cardiovasc Pharmacol. 1996;27:13-5.

10. Debebe $Y$, Yalemtsehay $M$, Asfaw D. In vivo antimalarial activities of fractionated etracts of Asparagus africanus in mice infected with Plasmodium berghei. Pharmacol Online. 2012;3:88-94.

11. Demissew S. Asparagaceae. In Edward S, Demissew S, Hedberg I, editors. Flora of Ethiopia and eritrea, vol. 6; 1997. p. 67-9.

12. Dikasso D, Mekonnen E, Debella A, Abebe D, Urga K, Mekonnen W, Melaku D, Aseffa A, Mekonnen Y. In vivo antimalarial activeity of hydroalcoholic extracts from Asparagus africanus Lam. In mice infected with Plasmodium berghei. Ethiopian J Health Dev. 2006;20(2):112-8.

13. Ezejiofor AN, Orish CN, Orish EO. Effect of aqueous leaves extract of costus afer Ker Gawl (Zingiberaceae) on the liver and kidney of male albino wistar rat. Ancient Sci Life. 2013;33:4-9.

14. Frances D, David S, Matthew S. Bruceantin, a potent amoebicide amoebicide from a plant Brucea antidysenterica. Antimicrob Agents Chemother. 1982;22(2):342-5.

15. Geremew T, Yalemtsehay M, Eyasu M. Antifertility effect of aqueous and ethanol extracts of the leaves and roots of Asparagus africanus in rats. Africa J Health Sci. 2006;6(2):81-5.

16. Hamid RR, Hasan Y, Leila H, Narges B, Mohammad K. Acute and subchronic toxicity of Teucrium polium total extract in rats. Iranian J Pharm Res. 2005:4:245-9.
17. Harden GJ. Asparagaceae. In Flora of New South Wales, vol 4. Sydney: Australia New South Wales University Press; 1993. p. 44-7.

18. Hayelo K, Mekbib A, Eyasu M, Wondwossen E, Kelbessa U. Toxicological investigation of chronic treatment with Clerodendrum myricoids on blood, liver \& kidney tissues of mice. MSc thesis, School of Graduate Studies AAU; 2009. p. 16-31 (submitted).

19. Himanshu M, Bhupendra KM, Dharam CJ. Optimization of extraction conditions and hptlc - uv method for determination of quinine in different extracts of Cinchona species bark. Rec Nat Prod. 2008;2(4):107-15.

20. Ibrahim A, Araidh MA, Tufail IA. Jammaz: toxicity of Cassia italica seeds to rats. Kuwait J Sci Eng. 2004;31(2):147-54.

21. Ilodigwe EE, Akah PA, Nworu CS. Evaluation of the acute and subchronic toxicities of ethanol leaf extract of Spathodea campanulata P. Beauv Int J Res Nat Prod. 2010;3(2):17-21.

22. Jaijoy K, Vannasiri S, Piyabhan P, Lerdvuthisopon N, Boonraeng S, Khonsung P, Lertprasertsuke N, Sireeratawong S. Acute and subchronic toxicity study of the water extract from the fruits of Piper chaba hunter in rats. Int J Appl Res Nat Prod. 2010;3(4):29-35.

23. Jemal DK. Toxicological Study of Glinus lotoides and Hagenia abyssinica: traditionally used taenicidal herbs in Ethiopia. A thesis, School of Graduate Studies, AAU; 2005. p. 43-74 (submitted).

24. Kumar G, Sharmila BG, Vanitha PP, Sundararajan M, Rajasekara PM Hepatoprotective activity of Trianthema portulacastrum L. against paracetamol and thioacetamide intoxication in albino rats. J Ethnopharmacol. 2004;92:37-40

25. Lord GM, Cook T, Arlt VM. Urotherial malignant disease and Chinese herbal nephropathy. Lancet. 2001;358:1515-6.

26. Oketch-Rabah HA, Dossaji SFJ, Christensen SB, et al. Antiprotozoal compounds from Asparagus africanus. J Nat Prod. 1997;60(10):1017-22.

27. Smith TW, Antman EM, Friedman PL, Blatt CM, Marsh JD. Digitalis glycosides: mechanisms and manifestations of toxicity. Prog Cardiovasc Dis. 1984;26:413-58.

28. Tan PV, Mezui C, Enow-Orock G, Njikam DT, Bitolog P. Teratogenic effects, acute and sub chronic toxicity of the leaf aqueous extract of Occimum suave wild lamiaceae in rats. J Ethnopharmacol. 2008;115(2):232-7.

29. Teklehaymanot T, Giday M. Ethinobotanical study of medicinal plants used by people in Zeige peninsula, Ethiopia. J Ethnobiol Ethinomed. 2007;3:1-3.

30. WHO. General Guidelines for Methodologies on Research and Evaluation of Traditional Medicine. WHO/EDM/TRM/2000.1.

\section{Submit your next manuscript to BioMed Central and we will help you at every step:}

- We accept pre-submission inquiries

- Our selector tool helps you to find the most relevant journal

- We provide round the clock customer support

- Convenient online submission

- Thorough peer review

- Inclusion in PubMed and all major indexing services

- Maximum visibility for your research

Submit your manuscript at www.biomedcentral.com/submit
() Biomed Central 